MedieKultur | Journal of media and communication research | ISSN 1901-9726

Book Review

\title{
Kirsten Drotner \& Sara Mosberg Iversen (red.): Digitale metoder. At skabe, analysere og dele data. Samfundslitteratur. 2017
}

\author{
Rikke Gaardboe
}

MedieKultur 2018, 64, 165-167

Published by SMID | Society of Media researchers In Denmark | www.smid.dk The online version of this text can be found open access at https://tidsskrift.dk/mediekultur

Det er altid godt at læse en bog, som dækker et hul i litteraturen. Og det gør Kirsten Drotner og Sara Mosberg Iversens Digitale metoder. At skabe, analysere og dele data. Redaktørerne af bogen tager fat i et vigtigt emne: Hvordan data indsamles, analyseres og deles med udgangspunkt i en digital kontekst. Den digitalisering, der er sket af samfundet, betyder også, for både forskere og studerende, at der er skabt nye muligheder for at undersøge digitale kommunikationsformer, relationer og netværk. Men det stiller også krav til andre metoder end de traditionelle kvalitative eller kvantitative metoder.

Bogens formål er at give en grundlæggende introduktion til, hvordan digitale metoder kan anvendes til at undersøge det digitale felt. Bogen henvender sig til forskere og studerende på videregående uddannelser, både i forelæsnings- og vejledningssituationer. De 248 sider er inddelt i 3 sektioner: Den første sektion består af 4 kapitler, som behandler, hvordan man skaber indhold. Vægten er primært lagt på, hvordan digitale data indsamles. Den anden sektion med 4 kapitler forklarer, hvordan indholdet kan analyseres ved hjælp af blandt andet Google Analytics, NVivo og Multimodal transskription. I den sidste sektion er der 3 kapitler. Her er omdrejningspunktet, hvordan det digitale felt bliver formidlet.

Man kan spørge sig selv om, hvorfor det er vigtigt at adressere, hvordan digitale data bliver skabt. Kan de metoder vi anvender på analoge data ikke blot anvendes på digitale data? Bogens pointe er, at metadata for analoge data er skabt af professionelle, hvor der er tydelige regler for kategorisering. Ved digitale data er der mindre regulering og heraf 
mindre tydelighed omkring kategoriseringen. Dette påvirker analysefasen. En anden væsentlig diskussion, som bogen også berører, er det etiske aspekt ved dataindsamlingen uden informeret samtykke. Det forhold, at de digitale data er offentligt tilgængelige, og der ikke er kontrol over distributionskanalerne, betyder, at det kan være vanskeligt at anonymisere datakilderne og de kanaler, data bliver distribueret igennem.

De færreste af os tænker over, at internettet både tilgængeliggør real-time data samt arkiverede data. I det første kapitel adresseres dette spørgsmål. Kapitlet fokuserer på, de implikationer de forskellige arkiveringsformer har for analyserne af digitale data. I et andet kapitel adresseres spørgsmålet også omkring historiske digitale data. Digitale arkiver muliggør, at vi kan undersøge fortiden ved hjælp af digitale data. Men hvor der er muligheder, er der også udfordringer. Det sidste centrale aspekt ved skabelse af digitale data er brugen af 'application programming interface' (API). Vitus Vestergaard formår at gøre en meget teknisk disciplin tilgængelig på en pædagogisk måde. Udover illustrative eksempler afsluttes dette kapitel med en tabel, der omhandler de overvejelser, der bør gøres inden API anvendes til dataindsamling. Hele den første del introducerer læseren til de digitale data og hvordan de kan høstes til brug for analyse.

Omdrejningspunktet for bogens anden del er, hvordan digitale data kan analyseres. Der er 2 kapitler om, hvordan NVivo kan anvendes til at analysere data. I det ene kapitel introduceres kvalitativ kodning i NVivo af Sara Mosberg Iversen. Udover at diskutere fordele og ulemper ved at anvende 'Computer Assisted Qualitative Data Analysis Software' (CAQDAS) giver hun også et konkret eksempel på, hvordan kvalitative data kan kodes. I det efterfølgende kapitel af Anders Stig Christensen tager han tråden op, hvor Sara Mosberg Iversen slap. Han fokuserer på brugen af CAQDAS i forbindelse med multimodalt digitalt materiale. Dette eksemplificeres ved hjælp af videomateriale, der transskriberes og analyseres. I kapitlet diskuteres også, hvordan komplekst og digitalt materiale analyseres.

Udover kodningsprocessen bliver dataanalyseprocessen også adresseret. Der er nogle metodiske udfordringer ved transformation af ustrukturerede data til visualisering. Forfatteren eksemplificerer, hvordan semantisk netværksanalyse kan anvendes til at undersøge begrebet 'miljø' inden for fedmeforskningen. En anden form for digitale data findes på de sociale platforme. Jakob Linaa Jensen har udviklet en heuristisk ramme, som kan anvendes i forbindelse med komparative analyser. Christian Kobbernagel introducerer Google Analytics, der kan bruges til at analysere websider. Han viser, hvordan Google Analytics kan bruges til at analysere data i forbindelse med et konkret websted. Forfatteren pointerer, at analysen skal tage udgangspunkt i en tydelig strategi og en klar kommunikationsforståelse.

En af de ting, som sjældent er behandlet i metodelitteraturen er, hvordan analysen af de digitale data bliver formidlet. Et af kapitlerne handler om det etiske aspekt ved formidling af sensitivt digitalt indhold. I dette tilfælde eksemplificeret ved hjælp af skanningsbilleder af fostre. Kapitlet er skrevet af Anette H. Grønning, som fokuserer på de metodiske 
Review: Digitale metoder. At skabe, analysere og dele data

problemstillinger i forbindelse med kommunikation, der deles online. Det sidste kapitel i bogen er skrevet af Sigurd Trolle Gronemann, som behandler, hvordan digitale redskaber kan skabe komplekse formidlingsprodukter.

Digitale metoder. At skabe, analysere og dele data er en gennemført antologi. Bogen er anbefalelsesværdig som en del af værktøjskassen i metode. Den formår på en rigtig god måde at balancere mellem forskningsbaseret viden og praktiske eksempler. Hvert kapitel afsluttes med en 'metodisk værktøjskasse', der giver praktiske anvisninger. Dette gør bogen meget anvendelsesorienteret i relation til studerendes projektarbejde eller opgaveløsning. Det er tydeligt at bogen er baseret på forskning, fordi der er rigtig gode referencelister, hvor læseren kan finde yderligere litteratur omkring de enkelte emner. Bogen er meget velskrevet og bestemt værd at læse.

Rikke Gaardboe

Videnskabelig assistent Institut for Ledelse og Økonomi

Aalborg Universitet gaardboe@business.aau.dk 